\title{
Competing Geopolitical Interests of China, Russia and the United States in Central Asia and the Caspian Region
}

\author{
Richard Rousseau
}

\author{
Khazar University, Baku, Azerbaijan
}

It is an open secret that Middle Eastern proven oil reserves are not sufficient to meet the increasing hydrocarbon needs of European and American economies. Finding new supply channels is of the utmost importance. Many countries have therefore begun to focus on the Caspian basin energy resources. However, extraction and export of these precious resources via the South Caucasus or South Asia would flout the regional energy monopoly of the Russian giant Gazprom, whose "Druzhba" pipeline, the most important of its network, crosses Ukraine to supply European markets.

In an attempt to counter Russia's "leverage" in the energy market of the former Soviet Union the United States, together with various European countries, has sponsored a number of important projects. The Nabucco pipeline, scheduled to be operational in 2018, will carry gas from Azerbaijan, Turkmenistan and possibly Kazakhstan to Europe, bypassing Russia to the south. Between 2002 and 2004 the Kremlin hindered the development of this project with the help of the Ukrainian government of pro-Russian Leonid Kuchma. However, following the November 2004 Orange Revolution and the election of liberal opposition leader Viktor Yushchenko as President, Ukraine changed course and endeavored to join Western-oriented political structures. It even expressed a clear wish to become a member of the North Atlantic alliance (NATO). This move evoked hard-line Russian criticism, especially from the ruling elite.

The election of Viktor Yanukovich in February 2010, which was followed by a dispute over the transparency of his the election instigated by his main rival, Yulia Timoshenko, in custody since August 2011 for having exceeded her authority in signing a gas agreement with Russia in 2009 while she was Prime minister, could again reverse Ukraine's position and, thereby, force a reconfiguration of the strategy of the various players involved in the frantic competition for Central Asia's energy resources, a contemporary competition similar to the infamous "Great Game" of the 19th Century. 
This article takes a look at the main protagonists' strategies and interests in the battle for the control of the extraction, transport, refining and consumption of Central Asian "black gold."

\section{Historical Context of the "New Great Game"}

The geopolitical significance of Central and South Asia has long been acknowledged. This vast region is considered to be the heart of the "World-Island," the vast landmass including Europe, Asia and Africa. Halford John Mackinder, one of the fathers of modern geopolitics, wrote in 1904: "Who rules East Europe commands the Heartland; who rules the Heartland commands the World-Island; who rules the World-Island controls the world." In these three simple sentences this classical scholar of geopolitics conveys the gist of his Heartland theory, which was destined to gain great currency in later decades, though subject to different interpretations. ${ }^{1}$ Mackinder's theory, according to many observers of the time, was to some extent validated by the so-called "Great Game," the long and debilitating struggle for power and influence in the nineteenth century between the Tsar and Her Majesty. Indeed, both the Russian and British Empires made continuing efforts to impose and maintain their dominance in Central Asia and the Caucasus.

Mackinder also referred to that same region as the "Heartland." This designation was first coined during the second half of the 1800s to describe the Central Asia and Caucasus territories then under Russian control. Inaccessible by sea, rich in oil and natural gas, these territories were the pivotal point of Tsarist Russia's strategy in the international arena. The imbalance of power imposed by the Congress of Vienna (1814-15), which divided up Europe after Napoleon's defeat, gave the Russian Tsar the opportunity to conquer the outlying territories of Eurasia and later exploit the vast energy resources they contained. The wealth thus derived gave St. Petersburg sufficient resources to construct a fleet strong enough, to compete with the British Empire's for control of the oceans.

The Mediterranean and Indian Oceans were priorities of the nineteenth century Tsarist administrations. However, their interest in these oceans waned after the Russian defeat in the Crimean War $^{2}$ (1853-1856), which changed the course of Tsarist foreign policy. After being overwhelmed by the Turks, who were supported by French and British troops, on the Crimean Peninsula, Russia aimed to expand its sphere of influence in Central Asia with a view to proceed south and secure an outlet to the Indian Ocean.

St. Petersburg's expansionist foreign policy quickly met tough opposition in Britain. India, under British control, and considered by Queen Victoria the jewel in the crown of the British Empire, was threatened by the continuous progress of 
Tsarist troops through Central Asia. This threat had to be eliminated. Accordingly, the British tried to assert their own superiority in Central Asia, threatening war over Afghanistan in both 1885 and 1904.The Afghan territory was turned into a buffer zone to protect the British colonies from the hegemonic pretensions of St. Petersburg. These events set off a long-lasting conflict in the second half of the 19 th century whose results continue to impact world politics today.

\section{The Strategic Importance of Central Asia Today}

Today this contested region again carries great influence on the geopolitical strategies of the dominant states. Geologists and industry experts confirm that the area contains a vast underground supply of hydrocarbons. ${ }^{3}$ These energy resources are not quantitatively comparable to those of the Persian Gulf, but are ample enough to satisfy, at least for a significant period of time, the gluttonous energy appetite of the major powers and could serve as an excellent substitute for Middle Eastern oil, whose supply is subject to continuous fluctuations due to the threat of Islamic fundamentalism, international terrorism and, since January 2011, "spontaneous" social revolutions. The richest deposits so far discovered are in the Caspian Basin, which is surrounded by Azerbaijan, Turkmenistan, Kazakhstan, Russia and Iran. Crude oil extraction in Azerbaijan increased from 180,000 barrel per day (bbl/d) in 1997 to 1.07 million bbl/d in 2010, according to OPEC. ${ }^{4}$ This South Caucasus country is also blessed with the largest known reserves of natural gas, production of which reached 583 Billion cubic feet $(\mathrm{Bcf})$ in 2010. Turkmenistan, another major regional gas supplier, produced 189,400 bbl/d of crude oil and 70.5 Bcf of natural gas in 2008. Uzbekistan also commands considerable hydrocarbon reserves, which in 2009 amounted to $59.4 \mathrm{Bcf}$ of gas and $60,820 \mathrm{bbl} / \mathrm{d}$ of oil. ${ }^{5}$ The Kazakh Caspian coast holds an impressive quantity of oil, production of which was running at 1.45 million bbl/d in 2007. Finally, in 2008 Iran exported 2.4 million barrels of oil per day to Asia and European countries belonging to the Organization for Economic Cooperation and Development (OECD). ${ }^{6}$

The role of Central Asia and the Caspian basin as a commercial hub should also not be underestimated. Since ancient times these regions have been a crossroads of land, sea and river routes. Centuries ago, the latter connected China with the Mediterranean and were the path taken by the caravans of camels loaded with precious and exotic oriental goods designated for Western markets. This commercial corridor was called by the German geographer and geologist Ferdinand von Richthofen the "Seidenstrabe" (Silk Road).

Tsarist, Soviet and modern Russian rulers have always considered Central Asia a strategic region. During World War II, and later during the Cold War between the United States and the Soviet Union, this territory acted as a strategic rear reservoir 
of energy for the powerful Soviet war machine. However, according to Zbigniew Brzezinski, who worked as an adviser to former U.S. president Jimmy Carter (1976-1980), the collapse of the USSR in 1991 left a partial power vacuum in that region. The rapid erosion of Moscow's control was accelerated by a few key factors: Ukraine's declaration of independence in 1991; Turkey's continued attempts to increase its influence in nearby Azerbaijan, Georgia and Armenia; the revival of nationalist fervor in all corners of the Soviet federation; Central Asian republics' attempts to reduce their economic dependence on the Soviet Union and post-Soviet Russia, although the developmental models adopted by these newly independent states still had a distinctly Soviet flavor.

Consequently, the early nineties brought to the forefront the need to diversify Central Asian countries' political and economic partners. However, the implementation of classical liberal policies designed to foster greater economic cooperation between Central Asian countries and, subsequently, regional political integration has proved extremely difficult because various practical obstacles have emerged. For instance, Kyrgyzstan, a poor and politically unstable country, was able to join the World Trade Organization (WTO) back in 1998, while Uzbekistan, Tajikistan, Kazakhstan, Afghanistan and Iran have so far only achieved observer status.

It quickly became only too apparent to the leadership of these countries that their weak economies were poorly diversified and, therefore, could not withstand the flood of goods imported from more powerful neighbors, particularly China, a country with various comparative and competitive advantages, including its geographical location. It also soon became necessary to adopt protectionist policies to safeguard national economies and focus primarily on putting social institutions on a sound footing. More foreign direct investment was also needed to lay down the transport infrastructure required for the enhancement of profitable trade in Eurasia and for greater economic and financial integration among the fragile Central Asian countries. Consequently, a no holds barred diplomatic struggle for influence between the great powers came into being, with each seeking a slice of the geopolitical cake in Central and South Asia.

Joseph Nye, a scholar at Harvard, ${ }^{7}$ believes that economic, political, social and religious global forces have catapulted nation-states into an increasingly interdependent world. The establishment of diversified and profitable trade relations and new routes for the export of large volumes of hydrocarbons are unavoidable if Central Asian states really want to ensure their financial, commercial, political and military development. This has opened the way for China, the United States and the European Union to participate in interesting commercial and energy deals in a region that was formerly, for over fifty years, the exclusive domain of Moscow. 
A new "Great Game" broke out in Central and South Asia in the 1990s and is still being played out in the second decade of the 21th century. It is now part of a process which could determine the structure of the international system. Washington, Beijing, Moscow and Brussels are each pursuing their own objectives in a region where the role played by small and medium-sized powers cannot be underestimated. The four great powers of the contemporary world cannot be merely passive spectators. They are now actively at work to determine who gets what, where and when in the geopolitics of Central and South Asia. This article takes a close look at the protagonists' interests and strategies to gain the upper edge in a vital region of the globe.

\section{The Protagonists of the Great Game}

\section{China}

The Chinese government's plan to build a high-speed rail network to connect the Far East with Central Asia and Europe is, among other reasons, a product of a clash between the great powers over Caspian and Caucasus energy resources. Dating back to the Prime Minister Li Peng (1987-98), the ambition to create a modern transport infrastructure in Eurasia took a large step forward in November 10, 2006, with the signing by representatives of eighteen countries of an agreement to implement the high-speed rail project. The network is expected to be completed by 2025 , with the consent and cooperation of the countries involved.

The project is a contemporary reinterpretation of the ancient Silk Road and an attempt to unite West and East, albeit in an environment of fierce competition with the Siberian railway, the historic and imposing Russian railway network through Eurasia which serves as the gateway between Siberia and European Russia. This high-speed train service is not intended solely for passenger use. A fundamental reason for this project is the emergence of new industrial centers in Eurasia, which have generated the need to speed up trade in goods, lower onshore transport costs, and facilitate the import of hydrocarbons.

Beijing's strategy, although simple, is carefully thought out. It wants to broaden its participation in, and cooperation with, countries on all continents, from Central and South America to South East Asia. To achieve this, it has decided to adopt the proven "African method," which consists of providing, at low cost, a technologically advanced railway system to the prosperous governments of energyrich countries in the Central Asian region. In exchange it will gain access to raw materials, including oil and natural gas. ${ }^{8}$

Hydrocarbons are indispensable in meeting the vast energy needs of the new economic Asian giant. However, China's strategy is perceived as a profound threat by Russian energy monolith Gazprom, which currently holds a monopoly in the 
region and tries to withstand mounting attacks on its position, particularly the geoeconomic ones coming from China and the United States. These take the form of ongoing pipeline project proposals, devised as viable alternatives to the existing pipelines controlled by Russian. ${ }^{9}$

\section{Chinese Interests in Central Asia}

The Chinese political agenda in Central Asia addresses two important priorities:

- ensuring the physical integrity of the People's Republic of China and securing the integrity of the region's national borders, thus promoting regional stability.

- obtaining a significant share of the vast energy resources of the former Soviet republics of Central Asia by establishing profitable and lasting economic ties with them.

Even during the Cold War Mao's China failed to carve out its own sphere of influence in Central Asia, which was subjected to a suffocating Soviet-style regency, and South Asia. However, this situation changed significantly in the early eighties, when the Chinese ruling class adopted a new approach in international relations: the so-called "Mulin Youhao," or "good neighborly policy." Since then, numerous efforts have been made by Beijing to engage in dialogue with its neighbors. Russia was the first courted country because of its geographic location and territorial size. Then, China turned its eyes towards Mongolia, India and the two Koreas, to finally intensify its diplomatic relations with Indonesia and Singapore. The implosion of the Soviet Union in 1991 meant the demise of the bipolar balance which for decades had been the cornerstone of the international order. This tectonic event created a geopolitical earthquake in Central Asia, which left a sort of black hole which the Chinese communist leadership sought to reap immediate profit from. ${ }^{10}$

Beijing set about reaching commercial, political and military agreements with Kazakhstan, Kyrgyzstan, Tajikistan, Uzbekistan and Turkmenistan. ${ }^{11}$ The volume of trade between the People's Republic and Central Asian states reached $\$ 465$ million in 1992 and 7.7 billion in 2004. ${ }^{12}$ In recent years, trade between China and Central Asian countries has increased significantly (see figure 1). In 2009 China for the first time exceeded Russia by volume of trade with the region. In 2010 trade turnover between Russia and Central Asian states reached \$22 billion, between China and Central Asia $\$ 29$ billion. The increasing volume of Chinese investments in the region and the growth of strategic goods export to China contribute to the rise of China as a major trade partner of Central Asia. The largest total trade among the five Central Asian countries is between China and Kazakhstan, amounting to around US $\$ 13.8$ billion in 2009. Yet this total is still smaller than the trade volume between China and Vietnam at US\$15.1 billion for the same year. ${ }^{13}$ In particular, 
following the agreement reached in 1998 with Kazakhstan over a border dispute, Beijing provided incentives to create greater bilateral economic cooperation between the Kazakh state and Xinjiang, a Chinese autonomous region with Turkic population significantly more open to trading with Central Asian political entities.

Figure 1 - Trade between China and its Neighboring countries
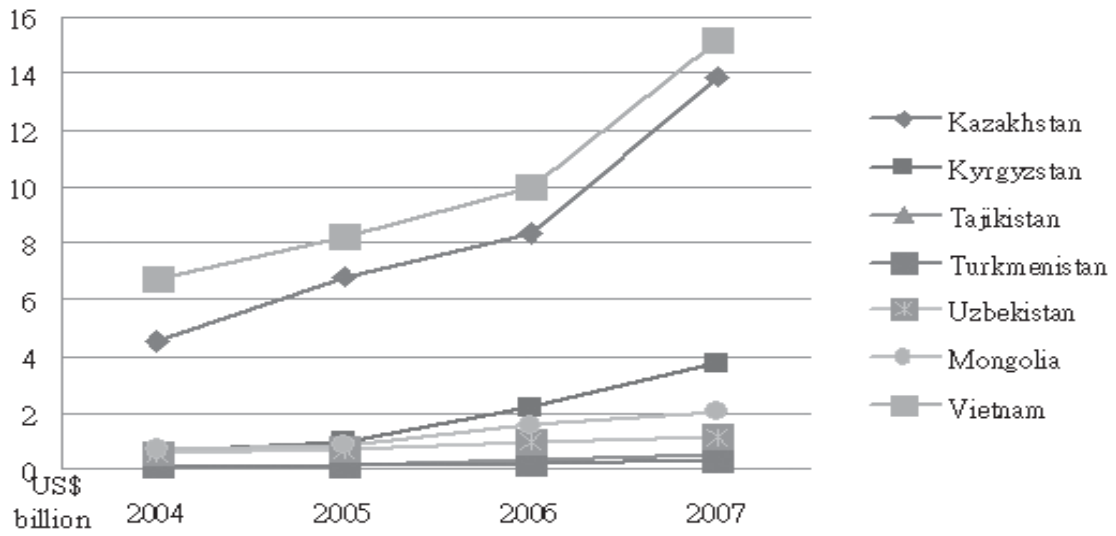

Source: Chinese Statistical Yearbook 2008 and 2006

The economic relationships Beijing has forged with regional players have been further facilitated by the complementarities between their economies. The adoption of the "African method" has enabled the Chinese ruling class to effectively play a poker game and achieve longstanding regional goals. Capturing access to the natural gas and oil fields was among its first priorities in Central Asia. The Chinese government has invested significant resources in building the infrastructure for the drilling, production and refining of Caspian and Caucasian hydrocarbons. This has been accompanied by the construction of an astute network of pipelines carrying hydrocarbons to China, bypassing Russia to the south, to satisfy the Chinese economy's ever-growing energy appetite.

The diversification of routes for the export of energy resources and the promotion of regional economic cooperation are efficient ways for China to combat Russia's energy monopoly, which is the predominant economic lever in the Kremlin's arsenal of "hard power." The TAPI (Turkmenistan-Afghanistan-Pakistan-India) pipeline project, which is supported by China and the Asian Development Bank (ADB) and envisions the transport of Turkmen oil to Beijing through Afghanistan, Pakistan and India, is one potent example of how China is now trying to outdo its neighbors, especially Russia, in Central and South Asia. ${ }^{14}$

In the last decade, China National Petroleum Corporation (CNPC), a state-owned enterprise, has signed various bilateral energy deals with Central Asian countries, ${ }^{15}$ 
which have also included the construction of roads and railways. Through these deals the Chinese authorities want to accelerate the transport of energy between China and its North Western neighbors. This in turn has opened the gate to a literal flood of agricultural and manufactured products from China to Central Asia. For China economic integration is not an end in itself but a prelude to deeper and more fruitful political and military integration.

Security and regional stability are other major priorities for the Chinese dragon. Beijing seeks to ensure its national integrity and sovereignty by promoting greater cooperation in combating the spread of separatism, extremism and terrorism. In particular, it has a preoccupation with preventing separatist and extremist movements spreading in Xinjiang. The rise of Islamic fundamentalism in Central and South Asia is disturbing for Beijing, since it has the real potential to threaten the regional stability which the Chinese rulers deem crucial for achieving their policy objectives. These regional circumstances accounted for the establishment of the Shanghai Cooperation Organization (SCO), which, from China's perspective, can form a useful instrument to develop greater economic and military cooperation in the fight against Islamic radicalism and terrorism. ${ }^{16}$

The SCO has the potential to help China extend its political and economic influence to Central Asian states, i.e., the countries which Russia, its main partner within this multilateral organization, is seeking to isolate by restoring an allencompassing control over these former Soviet republics. The fight against terrorism and the need to ensure regional stability are not seen in Beijing as necessary and expedient steps in securing regional supremacy. After the September 11, 2011 attacks, the U.S.-led "global war on terror" saw Washington setting up permanent bases in Uzbekistan, Kyrgyzstan, Tajikistan and Afghanistan. These bold actions prompted the Chinese leadership to take a markedly anti-American posture within the SCO. It was clear to China that the US wanted to impose its political and economic influence in the region. In the future, China will seek to counter Washington's competing claims in the area out of expediency and to torpedo the historic concept of Central Asia as being reserved to an exclusive domain of Tsarist Russia, the former Soviet Union and post-Soviet Russia.

\section{Russia}

The Central Asian region, rich in hydrocarbons, has always been on the political agenda of the Kremlin. Russia has sought to extend its imperial borders into Central and South Asia since the days of Tsarist autocracy. Stretching from Siberia to the Caucasus glaciers, the Russian Empire was well positioned to greatly benefit from the significant quantity of oil and natural gas found in the Caspian Sea, regarded for centuries as an internal Russian lake. However the massacres and widespread devastation of World War I taught Russia the clear lesson: multinational empires do not last forever. Following the "Phoney War" the German, Ottoman and Austro-Hungarian Empires collapsed, and the Tsarist Empire had 
already been itself consigned to oblivion in February 1917. Consequently, Russia's solid grip on the Central Asian region was reduced, albeit temporarily.

Despite the early promises of the Bolshevik revolution, and especially after the rise to power of Stalin's minions, the various ethnic groups and nationalities of the new Soviet political system were frustrated in their aspirations for independence and subjected to the control of a new empire, this time the Soviet Union. In the mid1930s Stalin took advantage of its huge supply of oil and natural gas to fuel the costly and massive Russian war machine in preparation for an expected military attack by Nazi Germany. Later, during the Cold War period, the Stalinist regime sought to excel in economic, technological and military terms as it became a genuine rival to the West, imposing a division of labor within the Soviet "federation" which reduced a number of Central Asian republics to the status of being mere suppliers of raw materials to other parts of the union.

After Stalin's death the inherent weaknesses of dictator's empire (the flaws of the centrally-planned economy, the indiscriminate exploitation of the satellite states and the social costs of industrialization) were brought out into the open. This marked the beginning of the de-Stalinization process. Khrushchev, between 1956 and 1964, and later Gorbachev in 1986-87, allowed a limited devolution of powers from Moscow to the various national governments which, perhaps inevitably, stoked the growth of independence movements and, in the Caucasus and Central Asia, radical Islamic groups which fervently, and often with violence, demanded self-determination. ${ }^{17}$ The weakening of the Soviet Union soon reverberated throughout the entire Central Asian region. The independence of Ukraine, Georgia, Armenia and Azerbaijan, achieved between April and August 1991, weakened the Russian position on the Black Sea, hindering any attempt by Moscow to maintain or rebuild a Eurasian empire.

Moreover, the former Soviet Central Asian republics, with the political and economic support of Turkey, Iran, Pakistan and Saudi Arabia, sought to free themselves from the vestiges of the Soviet regency. ${ }^{18}$ Consequently, Russia has been forced to share the vast energy resources of the Caspian basin with its former republics, which, relying on the financial support of Western powers (and China), have been able to export their gas and "black gold" through a complicated pipeline network by-passing Russian territory. Central Asian states' policies have given the U.S. extra leverage in its plans to further weaken Moscow's control over energy in the region through Gazprom. ${ }^{19}$

\section{Russian interests in Central Asia}

Russia's main interests in Central and South Asia are diverse. It fears the proliferation of regional independence movements tied to radical Islamic groups, which compromise its national security, a perception shared by China. Religious fundamentalism, in conjunction with the smuggling of weapons and drugs, 
continues to be a real threat. Since the early 1990s Moscow has committed a significant number of troops to Tajikistan to prevent the destabilizing effect of radical movements in nearby Afghanistan on neighboring countries. ${ }^{20}$

A second concern is energy, which is a strategic resource in character. ${ }^{21}$ Moscow is determined to retain a central role in the extraction and refining of oil, and particularly in the export of Caspian oil to Central Europe. Since huge quantities of the oil and gas exported by Russia to Eastern and Central Europe originate in the Caspian basin and Central Asia, it follows that a decrease in the European consumption of Russian energy would in the mid and long term drive a wedge between Moscow and the Central Asian republics and shatter their mutual friendship, to the ultimate benefit of the Euro-Atlantic countries. ${ }^{22}$ The Russian "South Stream" and "North Stream" pipeline projects should be interpreted as means of countering the NATO-Euro-Atlantic "energy offensive."

Furthermore, realizing that it is unable to tackle America's hegemonic ambitions in Central and South Asia alone, especially in the wake of shifts in the Bush doctrine and the adoption of the "global war on terror" in reaction to the attack on the Twin Towers in New York on 9/11, Moscow is keen to seek out "allies." It is willing to turn to those countries which share its concerns over the United States' encroachment in Central and South Asia. This strategic context has been propitious for a Russia-China rapprochement, as exemplified by the establishment of the Shanghai Cooperation Organization in 2001 and its founding goals. ${ }^{23}$

Relations between Washington and Beijing have deteriorated since 2005. Many consider that China's censorship of Google, Washington's concern over "currency manipulation" and the agreement between Taipei and Washington to supply Taiwan with 60 Blackhawk helicopters, 114 Patriot missiles and a range of advanced communications systems are the main factors contributing to the rise of U.S.-China tensions. Xi Jinping, the Chinese Vice President, visited Moscow on March 24, 2010 and noted that "the good relations, the relations of strategic partnership characteristic of our [China and Russia] countries, have not changed." 24 On that same day the two countries signed lucrative agreements to boost bilateral cooperation in the spheres of finance and industry. ${ }^{25}$ Relations between China and the U.S. cannot be overlooked by Russia or the Central Asian States as American consumers are the major buyers of Chinese manufactured goods and China the main creditor of the considerable U.S. government debt, holding vast quantities of treasury bills.

In an attempt to placate its ever-greater number of energy consumers, Beijing has concluded bilateral agreements with several Central Asian countries which eat into the Russian energy monopoly. For instance, in July 2009 China National Petroleum Corporation (CNPC) and the Kazakh oil company KazMunayGas completed the construction of the 962-kilometer Atasu-Alashankou oil pipeline, which runs from Atyrau in Kazakhstan to Alashankou in China's Xinjiang and gives the Chinese 
easier access to the vast energy supplies in the Caspian Sea. This project is perceived as somewhat of a "game changer" in the race to control the region's hydrocarbons. Similarly, in June 2006 CNPC signed an oil and gas exploration agreement with Uzbekneftegaz, which included five on-shore exploration blocks located in three large petroliferous Uzbek basins: Ustyurt, Amu Darya and Fergana. In 2008 the two state-owned companies signed a letter of intent to jointly boost the output of mature oilfields in the Fergana Basin. ${ }^{26}$

These various agreements are part of a larger expression of the underlying rivalry between Russia and China. The two ex-Communist rivals will require foresight and coordination if they are to achieve a level of mutual cooperation in weakening the U.S. presence in Central Asia.

\section{The United States}

The Orange Revolution in Ukraine in 2004/05 ushered in the presidency of proEuropean Viktor Yushchenko, who had been backed by the White House against the openly pro-Russian Prime Minister Viktor Yanukovich. Within a few months the Tulip Revolution in Kyrgyzstan then ousted Askar Akayev who was also too Russian-orientated in the eyes of Washington.

Kurmanbek Bakiev, the main Kyrgyz opposition leader, came to power and worked hard to consolidate the strings that could be pulled to make good his promise to dismantle the authoritarian system of the previous administration. However, he never really delivered. His administration proved to be one of tribes and bribes, a continuation of the clan rule which had characterized Akayev's regime. The levels of corruption and nepotism in the new government were even greater than in the previous one.

Bakiev also was faced with a multitude of other problems: economic crisis, exacerbation of the conflict between the competing clans who divided and ruled the population and a transient and unstable central administration that lacked resolve and was engulfed in corruption scandal. It was little wonder that these circumstances prevented the country from being able to focus on a clear foreign policy direction. However, perhaps due to a desire to have the best of both worlds, throughout his tenure Bakiev allowed both Russia and the United States to keep their military bases in Kyrgyzstan, at Kant (Russian, established in 2003) and Manas (U.S., in 2001) respectively.

On February 3, 2009, Bakiev announced that Manas Air Base would soon be closed, saying that economic considerations and the negative public attitude towards the base contributed to this decision. However, despite Russian pressure, he later reversed his decision and announced that the U.S. air base would be permitted to continue operating. 
Kyrgyzstan's revolt in March 2010, during which Bakiev was finally ousted from power, allowed another opposition leader, Roza Otunbayeva, to form an interim government. This revolt, which almost escalated into a civil war, can now be interpreted in retrospect as the product of apparently purely internal issues. The populace was pushed to rise against the Kyrgyz government out of sheer exasperation. It can also be construed as the fulfillment of the Kremlin's plan, mostly elaborated by the Russian Prime Minister Vladimir Putin and his clan, to counter and offset the ongoing wave of color revolutions (Georgia, Ukraine) which had only a few years before threatened Russian hegemony over Central Asia and the Caucasus as a whole. Moscow quickly recognized the Otunbayeva interim government, demonstrating its goodwill by extending a credit line of $\$ 150$ million.

The Kyrgyz upheaval held a high probability of reverberating, with significant political agitation, throughout Central Asia. This justified, at least to American policy-makers, the U.S. determination to maintain troops in Kyrgyzstan as part of the effort to achieve Washington's strategic objectives in Afghanistan and beyond. ${ }^{27}$

\section{U.S. Interests in Central Asia}

The United States' interest in Central Asia became more pronounced following the collapse of the Soviet Union in 1991. Washington's first priority was to remove the former republics from the orbit of communism and Moscow. In order to "decommunize" the region, the U.S. government tried to promote liberal economic and political reforms in the hope that it could transform these new states from socialist-type command economies into market-based economies. Thus in 1992 the Freedom Support Act was passed, leading to a total of $\$ 3.8$ billion being allocated to support regional economic development from 1992 to $2005 .^{28}$

Removal from the Soviet orbit was to be achieved not only through the spread of Western liberal values but also through the dismantling of military arsenals and the closing of Russian military bases in Central Asia. This strategy was exhaustively outlined in the 1995 document A National Security Strategy of Engagement and Enlargement, ${ }^{29}$ which promoted the export of developmental models aimed at promoting democratic institutions and free trade on the international level and the demilitarization of the post-Soviet area.

The U.S. strategic objectives in Central Asia also surfaced in the Silk Road Strategy Act of 1999. Great emphasis was placed on the need to develop closer and more profitable economic interaction between the region and the West. Such relations would promote trade and financial cooperation and vigorously counter the proliferation of nuclear weapons, drug trafficking, terrorism and endemic corruption. 
It was soon apparent though, as the Soviet regime became a historical relic, that Washington had an unambiguous interest in the region's energy resources. Since it had not yet found a valid replacement for Middle Eastern oil, the U.S. took the initiative to conclude agreements with energy supplier countries in Asia. ${ }^{30}$ Great efforts have been made to promote the construction of alternatives to the Russian energy corridors, including the Baku-Tbilisi-Ceyhan (BTC $)^{31}$ pipeline from the 2000 s and now the Nabucco and TAPI pipelines. ${ }^{32}$

The terrorist attack on the Twin Towers in September 2001 in New York, combined with a neo-conservative republican presidency, changed the priorities of presidential politics and the world scene. The "global war on terror" was seen by the American political class as an inevitable step to show what makes America tick and ensure that U.S. leadership, not only in Asia but throughout the post-bipolar world, remained intact.

Suddenly, Fukuyama's "End of History" theory proved "unreasonably optimistic." The Bush doctrine, as clearly expressed in the National Security Strategy of the United States of America ${ }^{33}$ pushed the need forward to forge a new U.S. foreign policy to deal with the perceived threat of Al Qaeda and to prevent the Afghan Taliban from remaining in power. Moreover, U.S. State Department supported a massive deployment of troops with a wide range of contractors in Kabul and, for that purpose, the ratification of bilateral agreements with such countries as Uzbekistan, Tajikistan and Kyrgyzstan.

The White House was able to access the military base at Karshi-Khanabad in Uzbekistan (the United States Air Force used the base between 2001 and November 2005) and established U.S. facility at the Manas airbase in Kyrgyzstan, while obtaining from Kazakhstan the right to fly over its territory to supply Manas and from Tajikistan an endorsement for the temporary use of the airport at Dushanbe. Important agreements for the exchange of information with regional states, other than Turkmenistan, were also concluded. ${ }^{34}$ Initially Washington could count on the support of the other regional players, notably China and Russia, when pursuing this strategy, as these countries were also concerned with curbing the spread of jihadist networks which threatened regional security and their own territorial integrity.

Consequently, Washington, for a time, penetrated ever further into the region with its campaign of "democratization" within the authoritarian Central Asian reality. However, this policy has now produced a mild "blowback" for American policymakers. In spite of its good intentions, the "modernization" process, in many respects, annoyed Central Asian leaders more than anything else. It ultimately undermined their relations with the U.S., and in the end, convinced their political elites that respect for human rights, reform programs, the creation of a democratic civil society and openness to free international trade would cause the rapid 
destabilization of their still-fragile regimes. They believed that only a strong, centralized authority could guarantee order. ${ }^{35}$

This substantial divergence of views with the U.S. led the Central Asian states to perceive negatively Washington's hegemonic inclination and prompted them to develop and strengthen their relations with Russia and China. ${ }^{36}$ Washington also declined to bestow substantive economic aid on this part of the world and, in the aftermath of the Andijan massacre in Uzbekistan in 2005, U.S. troops were evicted from the Uzbek military base. ${ }^{37}$

Moscow and Beijing, now fully aware of the geopolitical shift occurring in the region and ready to put aside their disagreements, saw an opportunity to benefit from the situation and opted for conditional cooperation against the common foe under the umbrella of the Shanghai Cooperation Organization (see figure 2).

In July 2005, during an SCO session in Astana, Russia, China, Kazakhstan, Kyrgyzstan, Tajikistan and Uzbekistan jointly requested that the U.S. set a date for the withdrawal of its troops from their territory. The 2010 uprising in Kyrgyzstan and the direction of the new government of Roza Otunbayeva have called the continuing American presence at the Manas airbase into question. This stance has coincided with a further threat to U.S. geostrategic interests in Central Asia which now opens up new and complicated scenarios in the "New Great Game" of the XXI Century.

Figure 2 - Chinese, Russian and American Economic Involvement in Central Asia

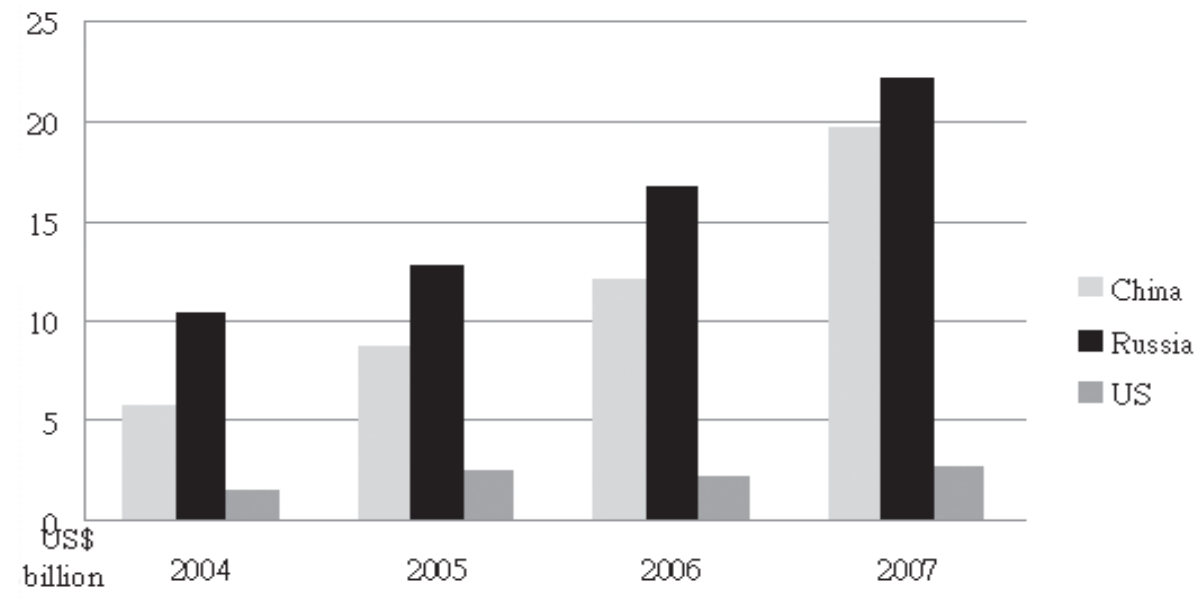

Source: Chinese Statistical Yearbook 2008 and 2006, Russia's Federal State Statistics Services and U.S. Census Bureau 


\section{References and notes:}

1. Nicholas J. Spykman (1893-1943), a Dutch-American geostrategist, developed a notable reinterpretation of Mackinder's geopolitical theory. Contrary to Mackinder, he put more emphasis on the concept of Rimland, which means that the great land and sea confrontation to establish world domination takes place near the Eurasian coast, not the Eurasian landmass.

2. St. Petersburg sought to secure an outlet to the Mediterranean in two different ways. The first was to gain control of the Balkans, which had been under Ottoman rule, the second to control the Dardanelles and the Bosphorus, again under Ottoman rule. The Russian strategy was to wait for resentment at the domination of the Sultan to grow and then intervene in a subsequent war against Turkish domination. Once the resentment had spread, Russian forces would fight alongside the local populations, which the tsar proclaimed himself to be the protector of - the Slavs of the Balkans were mostly Orthodox like the Russians - to reverse the Ottoman occupation of their land, and then impose Russian control over the region. The Tsar's hostility toward Turkish rule was hardened by the war aims of the United Kingdom, France and Piedmont, which supported Turkey. Indeed, the Crimean War marked the end, for a while, of Russia's military expansion around the Black Sea and of Nicholas I's pseudo-religious claims in the Balkans.

3. Bohr, A. (2004), Regionalism in Central Asia: New Geopolitics, Old Regional Order, International Affairs, $\mathrm{n}^{\circ} 80$ (3), pp. 485-502; Ahrend, R., W. Tompson (2007), Caspian Oil in a Global Context, Transition Studies Review, no 14 (1), pp. 163-87; Najman, B., et al. (2008), The Economics and Politics of Oil in the Caspian Basin. Routledge, London; Staniland, P. (2011), Caught in the muddle: America's Pakistan strategy, Washington Quarterly, 34(1) Winter, pp. 133-148; O'Hanlon, M., Riedel, B. (011), Plan A-minus for Afghanistan. In: Washington Quarterly, 34(1) Winter, pp. 123-132.

4. 'OPEC Expects Oil Production in Azerbaijan at $1.12 \mathrm{mln}$ bpd in the first quarter of 2011.'http://www.pfmc.az/index.php?option=com_content $\&$ view=article $\&$ id=433:opec -expects-oil-production-in-azerbaijan-at-112mn-bpd-in-i-quarter-of-

2011\&catid=1:latest-news

5. 'BP Statistical Review of World Energy, June 2010.' http://www.bp.com/liveassets/bp_internet/globalbp/globalbp_uk_english/reports_and_p ublications/statistical_energy_review_2008/STAGING/local_assets/2010_downloads/st atistical_review_of_world_energy_full_report_2010.pdf

6. Source: http://www.eia.doe.gov/

7. Nye, Joseph (2002), Globalism Versus Globalization, The Globalist, Monday, April 15. http://www.theglobalist.com/StoryId.aspx?StoryId=2392

8. Wu Lei, Liu Xuejun (2007), China or the United States: Which Threatens Energy Security?, OPEC Review, no 31 (3), pp. 215-234

9. Downs E., Maloney S. (2011), Getting China to sanction Iran: the Chinese-Iranian oil connection, Foreign Affairs, 90(2) March/April, pp. 15-21.

10. Garver, J.W. (2011), Is China playing a dual game in Iran? Washington Quarterly, 34(1) Winter, pp. 75-88.

11. Blank, Stephen (2010) The Strategic Implications of the Turkmenistan-China Pipeline Project, Jamestown Foundation, China Brief, vol. 10, No. 3, February 4, pp. 10-12. http://www.jamestown.org/programs/chinabrief/single/?tx_ttnews[tt_news]=36010\&x_t tnews[backPid] $=414 \&$ no_cache $=1$ 
12. Swanström, Niklas, Norling, Nicklas, Li, Zhang (2007), The New Silk Road: Transport and Trade in Greater Central Asia, Central Asia-Caucasus Institute \& Silk Road Studies Program, Johns Hopkins University, pp. 389-420.

http://www.silkroadstudies.org/new/docs/publications/GCA/GCAPUB-12.pdf

13. Li, Hak Yin,Wang, Zhengxu (2009), China's Advancements in Central Asia, East Asian Policy, Volume 1, Number 4, Oct/Dec, pp. 5-13.

14. Temple, David (2007), The Iran-Pakistan-India Pipeline, The Intersection of Energy and Politics, Institute of Peace and Conflict Studies (IPCS), 2007.

15. Foster, John (2008), A Pipeline through a Troubled Land: Afghanistan, Canada, and The New Great Energy Game, Foreign Policy Series (Canadian Centre for Policy Alternatives (CCPA)), Volume 3 No. 1, June 19.

16. The Taliban movement in Afghanistan and the Islamic Movement of Uzbekistan (IMU).

17. Dawisha, Karen, Parrott, Bruce (1994), Russia and the New States of Eurasia, The Politics of Upheaval, Cambridge University Press, pp. 1-22.

18. Brzezinski, Zbigniew (1997), The Grand Chessboard, American Primacy and it's Geostrategic Imperatives, Basic Books, pp. 121-166

19. Boussena, S., Locatelli C. (2005), Towards a More Coherent Oil Policy in Russia? OPEC Review, ${ }^{\circ} 29$ (2), pp. 85-105

20. Fumagalli, Matteo (2007), La dimensione strategica dell'Asia Centrale tra Russia, Cina e Stati Uniti, ISPI Policy Paper (Institute for the Study of International Politics and Italian Ministry of Foreign Affairs: Milan), No. 18, September, p. 4. http://www.ispionline.it/it/documents/wp_18_2007.pdf

21. Nanay, J. (2005), Russia and the Caspian Sea Region, in J. Kalicki y D. Goldwyn (eds.), Energy \& Security. Toward a New Foreign Policy Strategy, Woodrow Wilson Center Press, Washington, pp. 127-147.

22. Sagers M. (2007), Developments in Russian Gas Production since 1998: Russia's Evolving Gas Supply Strategy, Eurasian Geography and Economics, n 48 (6), pp. 65198.

23. Scalea, Daniele, Iran e Russia: amici o rivali? Eurasia, rivista di geopolitica, March 26, 2010. http://www.eurasia-rivista.org/iran-e-russia-amici-o-rivali/3592

24. 'Beijing and Moscow make the case for multi-polar global solutions,' Russia Today, March 24, 2010. http://rt.com/politics/beijing-moscow-global-solutions

25. Idem.

26. Swanström, op. cit., p. 392.

27. Madani, Amir, Russia: il cambiamento dei vertici in Kirghizistan, Limes, Revista Italiana di Geopolitica, March 21, 2010, http://temi.repubblica.it/limes/russia-ilcambiamento-dei-vertici-in-kirghizistan/12386?com=12386; Grazioli, trefano, Russia: le dinamiche del New Great Game, Revista Italiana di Geopolitica, March 21, 2010. http://temi.repubblica.it/limes/russia-le-dinamiche-del-new-great-game/12398

28. Aslan, Kursad (2007), U.S. Foreign Policy toward Central Asia: Institutions Matter, Allacedemic Research, February.

http://www.allacademic.com/meta/p_mla_apa_research_citation/1/8/0/6/1/p180615_ind ex.html

29. The White House (1995), A National Security Strategy of Engagement and Enlargement, February http://www.au.af.mil/au/awc/awcgate/nss/nss-95.pdf

30. Deutsch, J., Schlesinger, Victor D. (2006), Council on Foreign Relations (CFE), National Security Consequences of U.S. Oil Dependency, Independent Task Force Report, $\mathrm{n}^{\circ}$ 58; Sandalow, D., Ending (2007), Oil Dependence, The Brookings Institution, Washington. 
31. Rousseau, Richard (2008), Main Factors Contributing to the European Union's Policy Towards the Black Sea Region, Caucasus and Globalization Journal, Vol. 2, Issue 1, 2008, pp. 20-31.

32. Dadwal, Shebonti Ray, IPI or TAPI for India's Gas? The Diplomat, May 4, 2011 http://the-diplomat.com/indian-decade/2011/05/04/ipi-or-tapi-for-india\%E2\%80\%99sgas; Robert M Cutler, Iran gas pipeline to Pakistan on hold, The Asia Times Online, February 19, $2011 \mathrm{http}: / /$ www.atimes.com/atimes/South_Asia/MB19Df01.html

33. Bush, G. W., (2002), The National Security Strategy of the United States of America, Washington DC, September 20. http://www.globalsecurity.org/military/library/policy/national/nss-020920.pdf

34. Fumagalli, op. cit., p. 6.

35. Dunn, Jonathan (2009), Rethinking American Strategy in Central Asia, Midwest Political Science Association 67, the Annual National Conference, March. http://citation.allacademic.com/meta/p_mla_apa_research_citation/3/6/2/0/9/pages 3620 93/p362093-1.php

36. It is worth pointing out that the Uzbek government refused to allow an international investigation of the causes and implications of the Andijan massacres in May 2005. Protesting against the government in Tashkent, many demonstrators from Andijan were beaten, imprisoned, and even killed by the Uzbek police and military forces.

37. Aslan, op. cit., p. 17. 


\title{
Summary
}

\section{Competing Geopolitical Interests of China, Russia and the United States in Central Asia and the Caspian Region}

\author{
Richard Rousseau \\ Khazar University Baku, Azerbaijan
}

China and the United States have increased their role in Central Asia since the 1990s. Beijing was the driving force behind the creation of the Shanghai Cooperation Organization (SCO), which is considered by many to be an especially dynamic regional forum, with special relevance to Central Asia, not only in terms of trade, energy and security issues but as a political force that can be used to change the dynamics of the region. The increase of Chinese influence implies a progressive displacement of Russia, the traditional regional power, from its position of dominance. Russia's interests seem increasingly to be diverging from those of China in that part of the world, despite an apparent atmosphere of mutual understanding in their relations since the beginning of the 21 st century. In this article, the actions and interests of China, Russia and the United States in the spheres of trade, energy and state security are reviewed and analyzed with regards to the Central Asian-Caspian region. 